Article

\title{
Fertilization with Magnesium- and Sulfur-Supplemented Digestate Increases the Yield and Quality of Kohlrabi
}

\author{
Tomáš Lošák ${ }^{1}$, Tomáš Válka ${ }^{1}$, Jakub Elb1 ${ }^{1,2, * \mathbb{C}}$, Antonín Kintl ${ }^{2}$, Anna Keutgen ${ }^{3}$, \\ Norbert Keutgen ${ }^{3}{ }^{\circledR}$, Lenka Demková ${ }^{4}$, Július Árvay ${ }^{5}{ }^{\circledR}$, Ladislav Varga ${ }^{5}$, Hana Hnátková ${ }^{6}$, \\ Krzysztof Gondek ${ }^{7}$ (D) and Monika Mierzwa-Hersztek ${ }^{7}$ \\ 1 Mendel University in Brno, Zemědělská 1, 61300 Brno, Czech Republic; tomas.losak@mendelu.cz (T.L.); \\ 45211@node.mendelu.cz (T.V.) \\ 2 Agricultural Research, Ltd., Zahradní 1, 66441 Troubsko, Czech Republic; kintl@vupt.cz \\ 3 University of Natural Resources and Life Sciences Vienna (BOKU), Gregor-Mendel-Str. 33, 1180 Vienna, \\ Austria; anna.keutgen@boku.ac.at (A.K.); norbert.keutgen@boku.ac.at (N.K.) \\ 4 University of Prešov, 17. Novembra 3724/15, 08001 Prešov, Slovakia; lenka.demkova@unipo.sk \\ 5 Slovak University of Agriculture in Nitra, Tr. A. Hlinku 2, 94976 Nitra, Slovakia; \\ julius.arvay@uniag.sk (J.Á.); ladislav.varga@uniag.sk (L.V.) \\ 6 Research and Breeding Institute of Pomology Holovousy Ltd., Holovousy 129, 50801 Hořice, \\ Czech Republic; Hana.HNATKOVA@vsuo.cz \\ 7 University of Agriculture in Krakow, al. A. Mickiewicza 21, 31-120 Kraków, Poland; \\ rrgondek@cyf-kr.edu.pl (K.G.); monika.mierzwa@urk.edu.pl (M.M.-H.) \\ * Correspondence: jakub.elbl@mendelu.cz
}

Received: 15 June 2020; Accepted: 14 July 2020; Published: 16 July 2020

\begin{abstract}
The vegetation pot experiment with kohlrabi (Moravia variety) was established in 2014 and 2015. The experiment included four treatments of fertilization: (1) untreated control, (2) digestate, (3) digestate $+\mathrm{Mg}+\mathrm{S}$, and (4) digestate $+\mathrm{S}$. Treatments 2-4 were fertilized with the same $\mathrm{N}$ dose. Differences between the years were recorded in all parameters. Compared with the variant with digestate $(100 \%)$, the kohlrabi yield of the unfertilized variant was demonstrably lower in both years (33.1\% and 46.9\%). Digestate enriched with the fertilizer containing $\mathrm{Mg}+\mathrm{S}$ (treatment 3 ) demonstrably increased the yield of kohlrabi by $10.2 \%$ and $15.7 \%$ compared with pure digestate (treatment 2). Digestate enriched with the fertilizer containing elementary S (treatment 4) demonstrably increased the yield of kohlrabi (by 7.4\%) only in 2015 compared with pure digestate (treatment 2). Except for the year 2015, there were no yield differences between variants 3 and 4 . In both years, the lowest content of nitrates in kohlrabi was observed in the unfertilized control (135 and $163 \mathrm{mg} \mathrm{NO}{ }^{-} / \mathrm{kg}_{\mathrm{FM}}$, respectively). Following the application of digestate (treatment 2), the content of nitrates ( $\mathrm{mg} \mathrm{NO}_{3}{ }^{-} / \mathrm{kg}_{\mathrm{FM}}$ ) increased to 327 in 2014 and to 509 in 2015. The addition of fertilizers with $\mathrm{Mg}+\mathrm{S}$ as well as fertilizer with elementary $\mathrm{S}$ to the digestate (treatment 3 and 4 ) significantly reduced the content of nitrates to 295-301 $\mathrm{mg} \mathrm{NO}_{3}{ }^{-} / \mathrm{kg}_{\mathrm{FM}}$ (2014) and to $449-468 \mathrm{mg} \mathrm{NO}{ }^{-} / \mathrm{kg}_{\mathrm{FM}}$ (2015). The content of ascorbic acid did not statistically differ among the four treatments in the two years (268-281 and 311-329 mg/kg in 2014 and 2015, respectively). Digestate supplemented with Mg + S (magnesium sulfate) or only with elementary $S$ can be recommended for kohlrabi fertilization prior to the planting in order to reduce dangerous accumulations of nitrates in kohlrabi.
\end{abstract}

Keywords: digestate; magnesium; sulfur; kohlrabi; nitrate N; vitamin C 


\section{Introduction}

Farm materials such as farmyard manure, crop residues, waste from food industries, communal waste (household waste), and specific energy crops are the main raw materials for anaerobic digestion (AD) in biogas plants (BGPs). Biogas and digestate are the final products of the AD of input organic raw material into the BGP, which is an important source of renewable energy [1,2]. Digestate is normally used as fertilizer in agriculture [2,3].

Nevertheless, expanding biogas production currently evokes a number of new questions including the subsequent use of anaerobic residues from fermentation, i.e., digestate for agricultural purposes [4]. Therefore, extensive field and pot experiments have been conducted in the past, which either pointed out the beneficial effects of digestate application on arable land in terms of yields [5-7] or, in some cases, described non-significant effects on the grown crops. This particularly applies to specific vegetable species (cauliflower, for example) which cannot make use of nutrients readily available in the digestate. In such cases, the effect of digestate application is at the same level or even lower as compared with other vegetable species [8]. The effect of digestate has been most frequently studied in the conventional crops such as wheat and maize [9-11], namely thanks to the favorable content of available $\mathrm{N}[4,5]$, which has a significant influence on the yields of crops [12-14].

However, literature dealing with the application of digestate that would describe its use as a fertilizer for vegetables occurs very rarely. Expert opinions about the possibilities of using digestate as organic fertilizer in practice differ [4,15-17] because, for example, digestion is connected with extensive losses of organic C [18]. Digestate, a semi-solid residue obtained during AD after biomass extraction, is considered an important source of organic substances and nutrients, nitrogen in particular. Digestate has a certain amount of nutrients and organic substances and can be used as a soil conditioner or organic fertilizer; this is why its management has been currently gaining importance [19,20]. Möller et al. [3] found that up to $95 \%$ of the organic matter of the given raw material was degraded depending on the raw material composition. The produced digestate is rich in $\mathrm{N}$ and has a high proportion of $\mathrm{NH}_{4}{ }^{+}-\mathrm{N}$ compared with total $\mathrm{N}$, thus being potentially usable as fertilizer. Digestates contain high amounts of nitrogen, potassium, and phosphorus [21], while the contents of $\mathrm{Mg}$ and $\mathrm{S}$ are markedly lower. In addition to macronutrients, digestates contain micronutrients, too. Using digestates for fertilization can considerably save costs for purchasing mineral fertilizers [11,18]. Experiments were conducted with kohlrabi plants because they are rich in vitamin $C$ and group $B$ vitamins. These vegetables can also accumulate large amounts of potassium, calcium, iron, and magnesium, the latter being relatively underrepresented in the digestate. In addition, similar to all members of the Brassicaceae family, kohlrabi contains glucosinolates, S-containing compounds which are responsible for the vegetable's typical taste. Therefore, $\mathrm{S}$ is an essential compound, which has prompted us to select kohlrabi in the study with digestate which is low in the key macronutrients $\mathrm{Mg}$ and S [22,23].

This two-year study aimed at a comparison of the efficiency of digestate applied alone and digestate enriched with $\mathrm{Mg}$ and S (magnesium sulfate) or only with elementary S on the yield of kohlrabi, content of nitrates, and ascorbic acid in kohlrabi bulbs. The novelty of this approach is expressed in the following working hypotheses: (1) as a fertilizer, digestate is suitable for kohlrabi; (2) the application of digestate enriched with $\mathrm{Mg}$ and $\mathrm{S}$ or only with $\mathrm{S}$ will increase kohlrabi yield more than the application of digestate alone (with respect to the low Mg and S contents); (3) an increased content of ascorbic acid and reduced content of nitrates in the kohlrabi are assumed after the application of digestate enriched with $\mathrm{Mg}$ and $\mathrm{S}$ or only with S.

\section{Materials and Methods}

\subsection{Pot Experiment}

The pot experiments were established in the outdoor vegetation hall of Mendel University in Brno (Figure 1) in 2014 (27 May 2014) and in 2015 (28 April 2015). For them, a medium-heavy 
soil-Fluvisol—subtype modal was used. The weight of soil put into all Mitscherlich vegetation pots was $6 \mathrm{~kg}$. Agrochemical characteristics of the soil (methodology Mehlich III) were as follows: $\mathrm{pH} / \mathrm{CaCl}_{2}-7.6$ (slightly alkaline), content of available nutrients in $\mathrm{mg} / \mathrm{kg}: \mathrm{P}-49$ (low); $\mathrm{K}-166$ (satisfactory); $\mathrm{Mg}$ - 342 (good); $\mathrm{K} / \mathrm{Mg}$ ratio 0.48 (satisfactory). The four tested treatments were as follows: (1) unfertilized control, (2) digestate, (3) digestate enriched with $\mathrm{Mg}$ and S, and (4) digestate enriched with $S$ (Table 1). The experiment was set up with 4 replications per treatment.

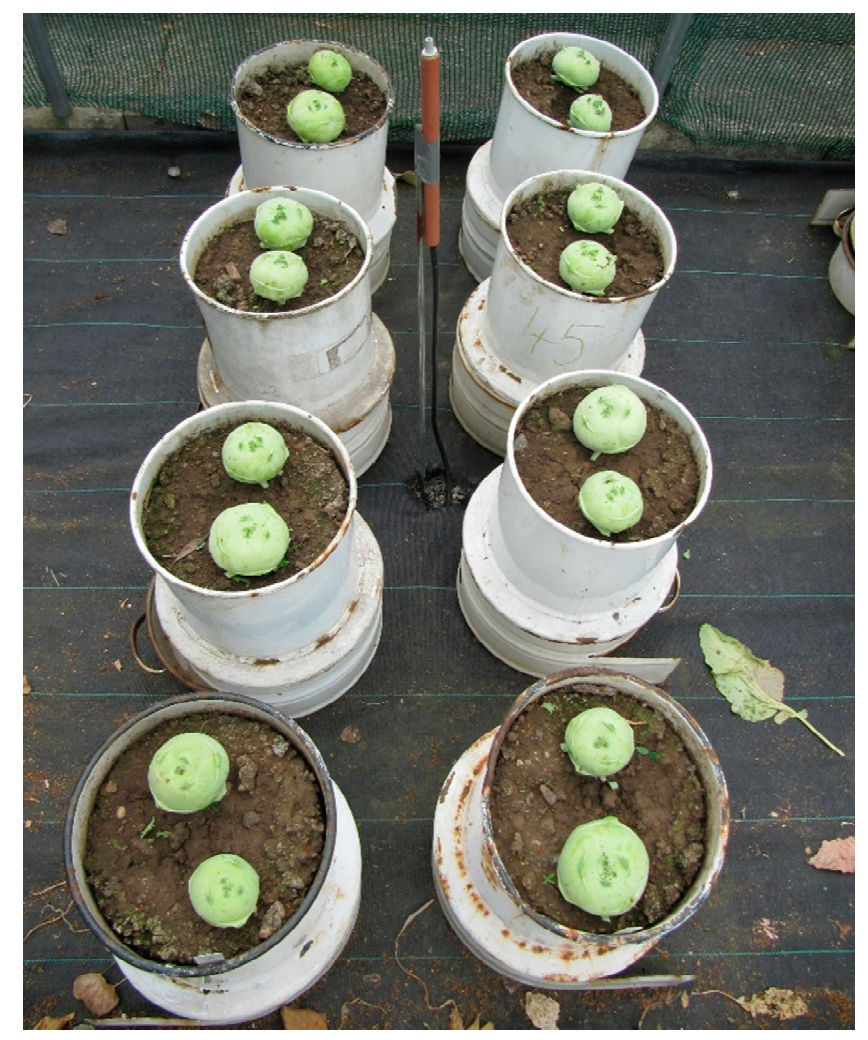

Figure 1. Localization of experimental pots in the vegetation hall (harvest).

Table 1. Experimental treatments.

\begin{tabular}{cccc}
\hline Treatment & Description & $\begin{array}{c}\text { Rate of Nutrients }(\mathbf{m g} / \mathbf{p o t}): \\
\text { N-P-K-Mg-S }\end{array}$ & Fertilizer Used \\
\hline 1 & Control & 0 & - \\
2 & Digestate & $1,500-240-1,350-140-50$ & digestate \\
3 & Digestate $+\mathrm{Mg}+\mathrm{S}$ & $1,500-240-1,350-280-240$ & digestate, EPSO TOP * \\
4 & Digestate $+\mathrm{S}$ & $1,500-240-1,350-140-240$ & digestate, elementary S * \\
\hline
\end{tabular}

* EPSO TOP = Magnesium sulfate (16\% MgO, 13\% S); elementary S = FERTI MK-S 800 SC (80\% S).

The chemical composition of digestate (dry matter content $6.99 \%$ ) was as follows (\% in fresh matter-FM): total $\mathrm{N}-0.537\left(0.375 \% \mathrm{~N}^{-N_{4}}{ }^{+}, 0.020 \% \mathrm{~N}^{-} \mathrm{NO}_{3}{ }^{-}\right) ; \mathrm{N}_{\text {org }}-0.142 \% \mathrm{P}-0.087 ; \mathrm{K}-0.483$; $\mathrm{Ca}-0.108 ; \mathrm{Mg}-0.051 ; \mathrm{S}-0.015$. Input material in the BGP was maize silage and pig slurry. The value of digestate $\mathrm{pH}$ was 8.16 and $\mathrm{C}: \mathrm{N}$ ratio was $4.8: 1$. The mineral fertilizers (treatments 3 and 4 ) were dissolved in water and thoroughly mixed with the digestate and soil in the container. The digestate itself (treatments 2-4) was thoroughly mixed with soil before filling the pots. The dose of $\mathrm{Mg}$ and S (treatment 3) in the fertilizer (EPSO TOP = magnesium sulfate) was $140 \mathrm{mg} \mathrm{Mg} /$ pot and $190 \mathrm{mg} \mathrm{S/pot}$ so that the total rate of $\mathrm{Mg}$ and S in treatment 3 was $280 \mathrm{mg} \mathrm{Mg} /$ pot and $240 \mathrm{mg}$ S/pot. The dose of elementary S (treatment 4) in the fertilizer (FERTI MK-S 800 SC) was $190 \mathrm{mg}$ S/pot so that the total rate of $S$ in treatment 3 was $240 \mathrm{mg} \mathrm{S/pot.}$ 
The planting of two kohlrabi plants (early Moravia variety) per pot was carried out 7-8 days after the pot set-up. Pre-grown plants at the two-leaf vegetation stage (BBCH 12 for Brassicaceae) were used. The containers were regularly watered to achieve $60 \%$ of water hold capacity and maintained without weeds. The crop was harvested at the stage of full maturity on the 18th of July and 29th of June in 2014 and 2015, respectively.

\subsection{Determination of Nitrates in the Bulbs}

The content of nitrates in kohlrabi bulbs $\left(\mathrm{mg} \mathrm{NO}_{3}{ }^{-} / \mathrm{kg}_{\mathrm{FM}}\right)$ was determined potentiometrically right after harvest in fresh matter by using an ion-selective electrode (Magic XBC, GRYF HB Ltd., Havlíčkův Brod, Czech Republic) according to Method 6210A (US EPA, OSWER). Upon the end of the experiment, two kohlrabi bulbs were harvested in each repetition of individual treatments (Figure 1), of which mixed samples were prepared for the subsequent analysis.

\subsection{Determination of Ascorbic Acid in the Bulbs}

The content of ascorbic acid $\left(\mathrm{mg} / \mathrm{kg}_{\mathrm{FM}}\right)$ was determined in FM by using the method of capillary isotachoforesy HP 1090 Series II, detector diode-array option 083 (Hewlett Packard, Palo Alto, CA, USA) according to Koh et al. [24]. Similarly, as in the determination of nitrate in the kohlrabi bulbs, the analysis was made using a mixed sample of biomass from the individual pots (repetitions) of all treatments.

\subsection{Statistical Analysis}

The measured data were processed in the Czech version of Statistica 12 (Dell Software, Round Rock, TX, USA). First, an exploratory data analysis (EDA) was performed to determine basic statistical parameters (expression of symmetry and sharpness at various distances from the median) in order to reveal possible extremes. Then, one-way analysis of variance (ANOVA) followed in combination with the post-hoc Fischer LSD test which was to reveal significant differences in the respective parameters among the treatments. All analyses were performed at a level of significance $p<0.05$.

\section{Results and Discussion}

\subsection{Weight of Single Bulbs}

Low nitrate nitrogen concentration in the soil can cause significantly reduced yields $[12,25]$, which is especially true for the kohlrabi due to the high uptake of this element [26]. Sharof and Wier [27] assessed the minimum amount of $\mathrm{N}$ required by various vegetable species including kohlrabi in relation to the components of $\mathrm{N}$ balance in the soil and found out that $\mathrm{N}$ requirements were at all times lower than values from field experiments.

In our pot experiment, differences between the fertilized variants and the unfertilized control were already visually clear at the beginning of the vegetation period. Furthermore, in later growth stages, the plants of the unfertilized control exhibited slower growth of above-ground biomass and a lighter color than fertilizer treatments. At harvest, the plants of unfertilized variant showed apparent symptoms of phosphorus deficiency (violet coloration), which resulted both from the low $\mathrm{P}$ content in the soil and from the soil reaction $(\mathrm{pH})$ unfavorable for its uptake.

Figure 2 shows yields in the respective years of the experiment. Kohlrabi yields in grams per pot (Figure 2) significantly varied in the respective years. Statistical differences and relative difference between the treatment fertilized only with digestate and the other treatments are presented in Figure 2. The unfertilized control (treatment 1 ) exhibited in both years a significantly lower yield of kohlrabi bulbs at a level of $33.1-46.9 \%$ (Table 2) as compared with treatment 2 with digestate (100\%). It is obvious that it was a positive synergistic effect of the nutrients in the digestate on yield-both macroelements (with the emphasis on $\mathrm{N}$ and $\mathrm{K}$ ) and meso elements. It follows that $\mathrm{N}$ is the most important element for yield, as mentioned by Feller et al. [26] and Lošák et al. [4,18]. 


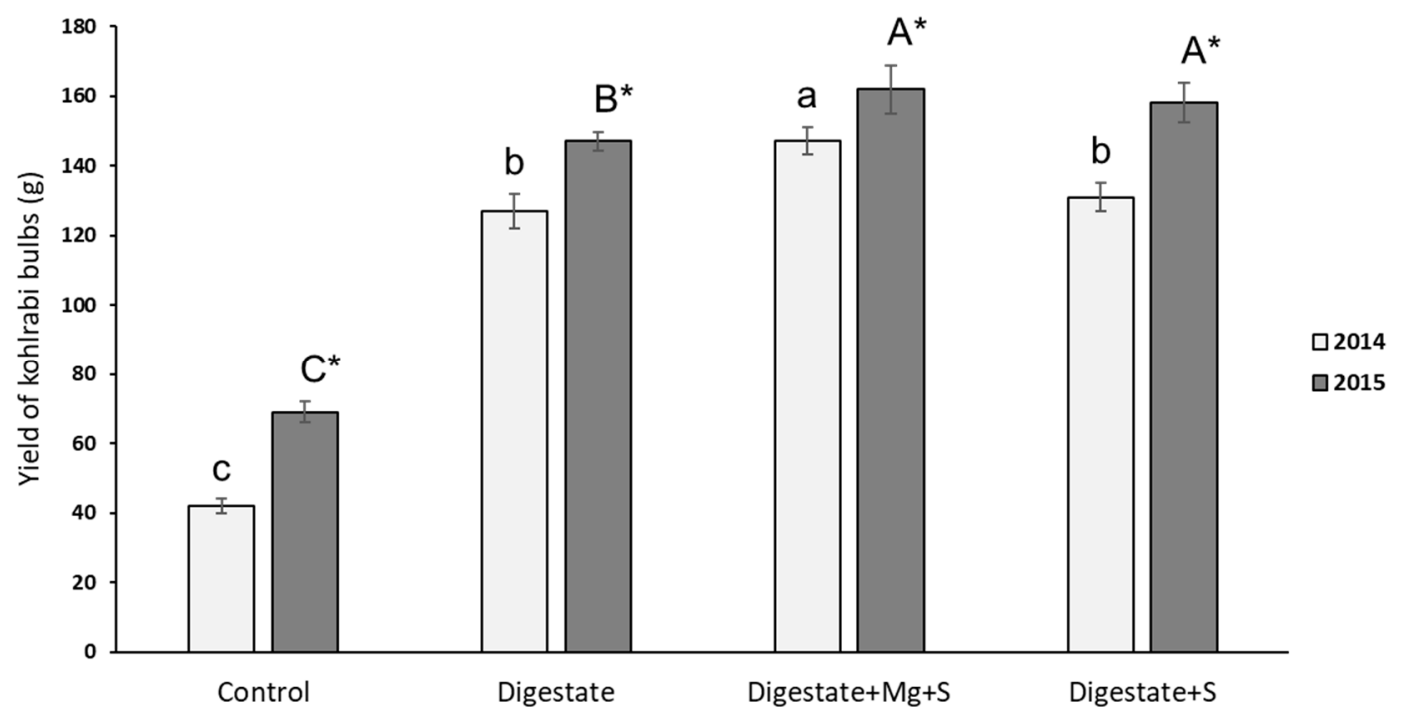

Figure 2. Yield of kohlrabi bulbs during the two years of the experiment. Comment on Figure 2: Mean values of kohlrabi bulb weights in $\mathrm{g}(\mathrm{n}=4 \pm \mathrm{SD})$ are shown. Different small letters indicate statistical differences between the individual variants in 2014 and uppercase letter in 2015 at a level of significance $p<0.05$. The symbol * shows the presence of significant differences between the individual years of the experiment in one treatment.

Table 2. Relative differences in the bulb weights.

\begin{tabular}{cccc}
\hline \multirow{2}{*}{$\begin{array}{c}\text { Treatment } \\
\text { No. }\end{array}$} & Description & $\mathbf{2 0 1 4}$ & $\mathbf{2 0 1 5}$ \\
\cline { 3 - 4 } & & Rel. \% & Rel. \% \\
\hline 1 & Control & 33.1 & 46.9 \\
2 & Digestate & 100.0 & 100.0 \\
3 & Digestate $+\mathrm{Mg}+\mathrm{S}$ & 115.7 & 110.2 \\
4 & Digestate $+\mathrm{S}$ & 103.1 & 107.4 \\
\hline
\end{tabular}

Rel. \% represents a percentage difference in bulb yields in all treatments compared to the digestate treatment.

In multi-annual experiments with three different types of digestate, Stinner et al. [5] described the positive influence on wheat yields as well. Similarly, Bath et al. [10] claimed higher yields of leek after fertilization with digestate as compared with compost, which was also expected because of the different efficiency rates of the two fertilizers, given by different $\mathrm{C}: \mathrm{N}$ ratios. In our experiment (Table 2), yield demonstrably increased by $10.2-15.7 \%$ following the application of digestate supplemented with $\mathrm{Mg}+\mathrm{S}$ (treatment 3) compared with the treatment with pure digestate (treatment 2). The soil used in the experiment had a good supply of $\mathrm{Mg}$, but although it was well supplied with this nutrient, fertilization was necessary and based on the balance method (nutrient consumption normative $\times$ yield). In 2014, the addition of elementary $S$ to digestate (treatment 4 ) raised the yield non-significantly by $3.1 \%$, whereas in 2015 , it significantly stimulated the yield by $7.4 \%$ compared with the application of digestate alone (treatment 2). Elementary $S$ is available to plants only after its oxidation into sulfates in the soil and has an acidifying effect on the soil [28,29]. In our experiment, soil reaction was 7.6 (slightly alkaline), which is good for the application of fertilizers with the elementary form of $\mathrm{S}$ because the fertilizers have an acidifying effect. Petříková et al. [30] stated the uptake of $0.3 \mathrm{~kg} \mathrm{Mg}$ and $1.5 \mathrm{~kg} S$ per $1 \mathrm{t}$ of kohlrabi yield, i.e., high uptake of both of these nutrients especially by late varieties yielding about $45 \mathrm{t} / \mathrm{ha}$. Wang et al. [31] described fertilizers with $\mathrm{Mg}$ generally promoting the yield of many crops with the fluctuation of yield increase being caused by crop species, soil conditions, fertilizer form, and other factors and with the average demonstrable yield of vegetables increased by $8.9 \%$. Although the EPSO TOP fertilizer is of Mg nature, it contains $S$ too as a sulfate ion; $S$ supports nitrogen utilization, at the same time stimulating yields and reducing the risk of $\mathrm{N}$ losses such as the leaching of 
nitrates into groundwater [27]. It can be assumed that the interaction of the two nutrients, $\mathrm{Mg}$ and S, contributed to the increase of kohlrabi yields in treatment 3 in both years.

\subsection{Content of Nitrates in the Bulbs}

Kohlrabi is classified in the group of vegetables with a higher risk of the accumulation of nitrates in tissues. Contents of $\mathrm{NO}_{3}{ }^{-}$in plants are namely affected by species-specific factors, $\mathrm{N}$ fertilization, type of $\mathrm{N}$ fertilizer, part of the plant, growth stage, and $\mathrm{S}$ content in the plants [5,32-34]. The lowest content of nitrates in the bulbs was found in the two years in the unfertilized control, 135 and $163 \mathrm{mg}$ $\mathrm{NO}_{3}{ }^{-} / \mathrm{kg}_{\mathrm{FM}}$, respectively (Figure 3). Following the application of digestate (treatments 2-4), the content of nitrates significantly increased in both years to $295-327 \mathrm{mg} \mathrm{NO}_{3}^{-} / \mathrm{kg}_{\mathrm{FM}}$ in 2014 and to $449-509 \mathrm{mg}$ $\mathrm{NO}_{3}{ }^{-} / \mathrm{kg}_{\mathrm{FM}}$ in 2015 compared to the unfertilized control. Treatment 3 and 4 did not exhibit any significant mutual differences. Following the addition of fertilizer with $\mathrm{Mg}$ and S (treatment 3 ) and fertilizer with $S$ alone (treatment 4 ), the content of nitrates in the bulbs demonstrably dropped in both years of the pot experiment by $8.0-9.8 \%$ (2014) and by $8.1-11.8 \%$ (2015), respectively. (Table 3) $\mathrm{S}$ is a part of the nitrite reductase enzyme which helps to reduce nitrates in plants. S deficiency may raise the nitrate level and stimulate the accumulation of non-protein nitrogen in the leaves [35,36]. Hlušek et al. [37] also stated that $S$ deficiency in vegetables increases nitrate accumulation. In some vegetables, $\mathrm{S}$ fertilization may decrease the concentration of nitrate $[38,39]$, as seen in the present research (treatment 3 and treatment 4 ).

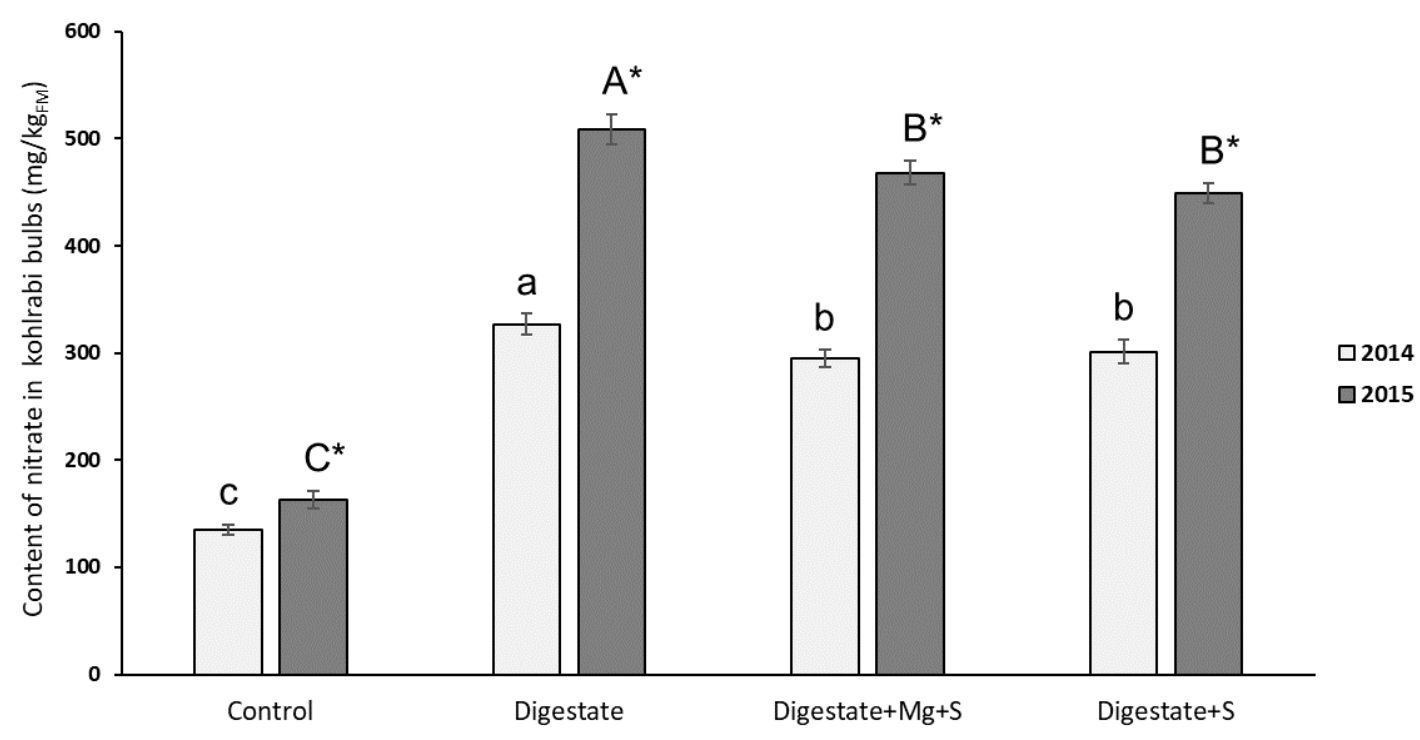

Figure 3. Content of nitrate in the kohlrabi bulbs during the two years of the experiment. Comment on Figure 3: Mean values of $\mathrm{NO}_{3}{ }^{-}$content in the kohlrabi bulbs in $\mathrm{mg} / \mathrm{kg}_{\mathrm{FM}}(\mathrm{n}=4 \pm \mathrm{SD})$ are shown. Different small letters indicate statistical differences between the individual variants in 2014 and uppercase letter in 2015 at a level of significance $p<0.05$. The symbol * shows the presence of significant differences between the individual years of the experiment in one treatment.

Table 3. Relative differences in the content of nitrate $\left(\mathrm{NO}_{3}{ }^{-}\right)$in the kohlrabi bulbs.

\begin{tabular}{cccc}
\hline \multirow{2}{*}{$\begin{array}{c}\text { Treatment } \\
\text { No. }\end{array}$} & Description & $\mathbf{2 0 1 4}$ & $\mathbf{2 0 1 5}$ \\
\cline { 3 - 4 } & & Rel. \% & Rel. \% \\
\hline 1 & Control & 41.2 & 32.0 \\
2 & Digestate & 100.0 & 100.0 \\
3 & Digestate $+\mathrm{Mg}+\mathrm{S}$ & 90.2 & 91.9 \\
4 & Digestate $+\mathrm{S}$ & 92.0 & 88.2 \\
\hline
\end{tabular}

Rel. \% represents a percentage difference in $\mathrm{NO}_{3}{ }^{-}$content in all treatments compared to the digestate treatment. 
Lošák et al. [18] mentioned similar results in their experiments with kohlrabi (Segura F1 variety) with the lowest content of nitrates recorded in the unfertilized variant and the highest content of nitrates after the application of urea $\left(678 \mathrm{mg} / \mathrm{kg}_{\mathrm{FM}}\right)$, while it demonstrably decreased to $228 \mathrm{mg} / \mathrm{kg}_{\mathrm{FM}}$ following the application of digestate. The reason for this situation might have been the fact that digestates contain a certain share of organic $\mathrm{N}(25-50 \%)$ which is mineralized in the soil within a certain period of time [40]. It is possible to assume that only a part of the organically bound nitrogen was mineralized during the short vegetation period of kohlrabi (approx. 6-7 weeks). Thus, mineral nitrogen $\left(\mathrm{N}-\mathrm{NH}_{4}{ }^{+}\right.$) became available to the plants from the digestate (or $\mathrm{N}-\mathrm{NO}_{3}{ }^{-}$after its nitrification) for achieving yield but the increase in the content of nitrates in the bulbs was smaller than after the application of urea (benefit to human health) [28,29].

\subsection{Content of Ascorbic Acid in the Bulbs}

Vitamin C, including ascorbic acid and dehydroascorbic acid, is one of the most important parameters of quality in vegetables with a range of benefits for human health. The content of vitamin $C$ in vegetables is affected by various factors such as vegetable species, climatic conditions before harvest, method of growing, maturity, harvesting methods, and post-harvest processing [41].

The ascorbic acid content did not differ among the four treatments in the two experimental years, ranging from 268 to $281 \mathrm{mg} / \mathrm{kg}_{\mathrm{FM}}$ in 2014 and from 311 to $329 \mathrm{mg} / \mathrm{kg}_{\mathrm{FM}}$ in 2015 (Figure 4), but its values were significantly higher in 2015 (Figure 4). Relative differences between the treatment fertilized with digestate alone and the other treatments ranged from $1 \%$ to $6 \%$ (Table 4 ). These values indicate a lower effect of the supplementation of other nutrients to the digestate on the content of vitamin $C$ in the kohlrabi bulbs. Thus, demonstrable statistic differences were observed only between the experimental years but not among the respective variants within a year. Nevertheless, in experiments with the kohlrabi of Segura F1 variety [18], a higher content of ascorbic acid was recorded in all fertilized variants $\left(772-789 \mathrm{mg} / \mathrm{kg}_{\mathrm{FM}}\right)$ as compared with the unfertilized variant $\left(511 \mathrm{mg} / \mathrm{kg}_{\mathrm{FM}}\right)$.

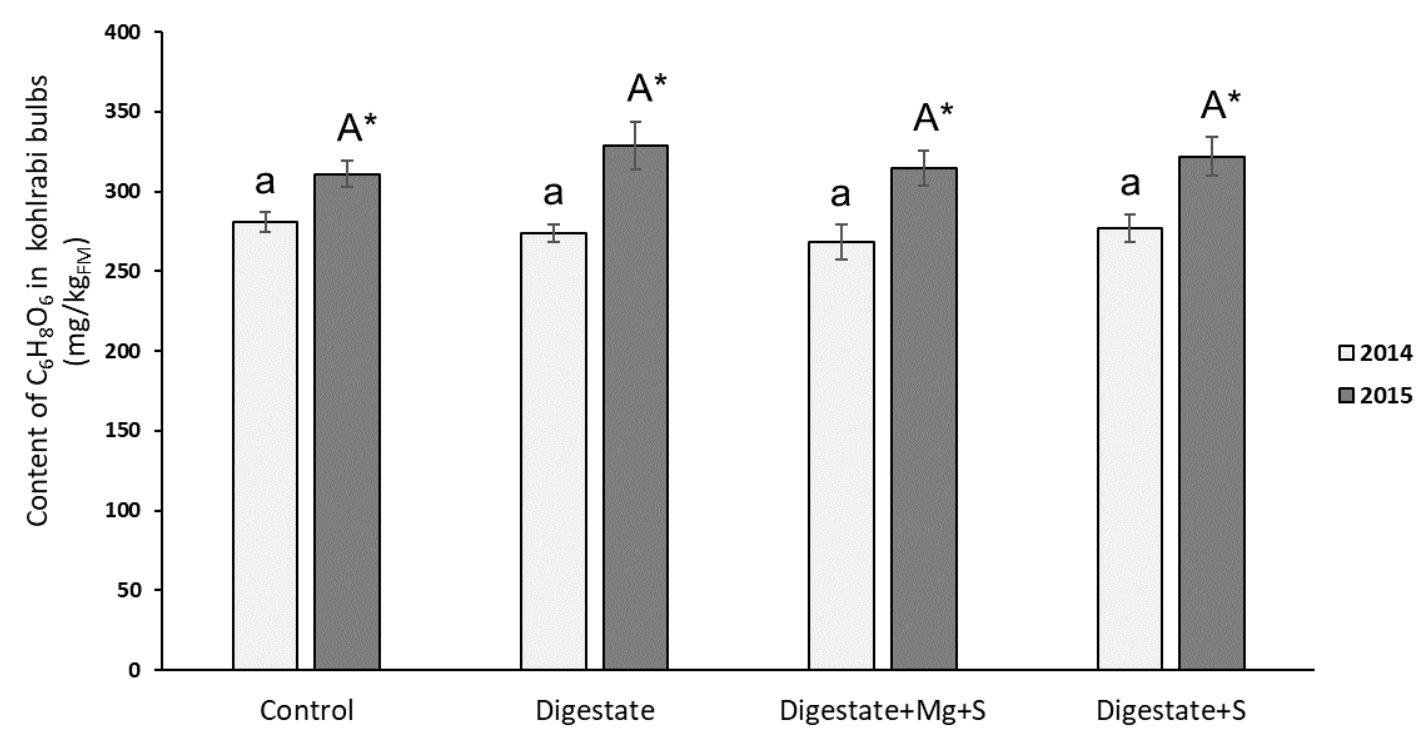

Figure 4. Content of ascorbic acid $\left(\mathrm{C}_{6} \mathrm{H}_{8} \mathrm{O}_{6}\right)$ in the kohlrabi bulbs during the two years of the experiment. Comment on Figure 4: Mean values of ascorbic acid $\left(\mathrm{C}_{6} \mathrm{H}_{8} \mathrm{O}_{6}\right)$ content in the kohlrabi bulbs in $\mathrm{mg} / \mathrm{kg}$ FM $(\mathrm{n}=4 \pm \mathrm{SD}$ ) are shown. Different small letters indicate statistical differences between the individual variants in 2014 and uppercase letter in 2015 at a level of significance $p<0.05$. The symbol * shows the presence of significant differences between the individual years of the experiment in one treatment. 
Table 4. Relative differences in the content of ascorbic acid $\left(\mathrm{C}_{6} \mathrm{H}_{8} \mathrm{O}_{6}\right)$.

\begin{tabular}{cccc}
\hline \multirow{2}{*}{$\begin{array}{c}\text { Treatment } \\
\text { No. }\end{array}$} & Description & $\mathbf{2 0 1 4}$ & $\mathbf{2 0 1 5}$ \\
\cline { 3 - 4 } & & Rel. \% & Rel. \% \\
\hline 1 & Control & 102.6 & 94.5 \\
2 & Digestate & 100.0 & 100.0 \\
3 & Digestate $+\mathrm{Mg}+\mathrm{S}$ & 97.8 & 95.7 \\
4 & Digestate $+\mathrm{S}$ & 101.1 & 97.8 \\
\hline
\end{tabular}

Rel. \% represents a percentage difference in the $\mathrm{C}_{6} \mathrm{H}_{8} \mathrm{O}_{6}{ }^{-}$content in all treatments compared to the digestate treatment.

Han et al. [42] investigated the effect of $\mathrm{MgSO}_{4}$, amino-acid-chelated $\mathrm{Mg}$ (Mg-AA), and Mg-EDTA on the quality of Chinese cabbage. In their experiment, the vitamin $C$ content increased only in the Mg-AA treatment. The other Mg sources resulted only in the increased yield. On the contrary, Borowski et al. [43] found that the foliar application of $\mathrm{Mg}$ salts on spinach resulted in decreased vitamin C content. Comparing cruciferous and non-cruciferous vegetables, Albrecht et al. [44] described the initial ascorbic acid content correlating with the $S$ content. Previous studies differed in their conclusions regarding the effect of $\mathrm{N}$ fertilization on the content of vitamin $\mathrm{C}$. Mozafar et al. [45] found that high doses of $\mathrm{N}$ fertilizers seemed to reduce the content of vitamin $\mathrm{C}$ in a number of vegetable crops. Similar findings were published by Smatanová et al. [46], according to whom, the content of ascorbic acid in spinach decreased from 57.5 to $51.9 \mathrm{ppm}$ with the dose of nitrogen increasing from 0.6 to $0.9 \mathrm{~g} \mathrm{~N} /$ pot. In the same experiments with spinach [46], the addition of $S$ to nitrogen reduced the content of ascorbic acid while in our experiments the content of ascorbic acid did not change. On the other hand, Nilsson et al. [47] found that $\mathrm{N}$ fertilization did not affect the content of vitamin $\mathrm{C}$ in cauliflower. Maurya et al. [48] demonstrated a significant increase in vitamin C content in connection with higher doses of nitrogen. Our achieved results and other experiences show that the content of vitamin $C$ in plants is influenced by several factors, such as the type of crop, variety, fertilization, and especially the effect of the year, which was confirmed in our experiments.

\section{Conclusions}

Values measured in our experiment confirmed that digestate represents a suitable fertilizer that can be applied in the production of vegetables, specifically kohlrabi bulbs. If we take into account that digestate can be prepared from diverse types of plant biomass, the model of its use in the fertilization/growing of crops for food products increases its potential in terms of sustainability. However, it has been critically stated that digestates from biogas plants are poor in $\mathrm{Mg}$ and $\mathrm{S}$. Therefore, the addition of both $\mathrm{Mg}$ and $\mathrm{S}$ additionally increased the kohlrabi yield and is particularly recommended here for the cultivation of Brassicaceae. A comparison with the results achieved with pure digestate shows that, according to the law of the minimum, the supplementation with magnesium and sulfur from mineral fertilizers increases the efficiency of the utilization of other macro- and micronutrients, resulting in the reported yield increase.

Supplementation of digestate with $\mathrm{Mg}$ and $\mathrm{S}$ has no negative influence on the contents of nitrates and vitamin C. Critical nitrate concentrations, e.g., for preserved, deep-frozen, or frozen spinach or for lettuce grown in the open, are $2000 \mathrm{mg} \mathrm{NO} / \mathrm{kg}_{\mathrm{FW}}$, i.e., among the lowest critical levels tolerated (Commission Regulation EU No. 1258/2011). The nitrate concentrations measured in the presented experiment for kohlrabi were distinctly lower than the critical levels $\left(<500 \mathrm{mg} \mathrm{NO}_{3} / \mathrm{kg}_{\mathrm{FW}}\right)$, although the application of the digestate with or without fertilizer resulted in a significant increase when compared to the control. It is worth noting that the nitrate content of baby foods for infants and young children must be lower than $200 \mathrm{mg} \mathrm{NO} / \mathrm{kg}_{\mathrm{FW}}$. Thus, in the case of kohlrabi, the application of digestate cannot be recommended for baby-food production. The concentration of ascorbic acid was not significantly affected by the treatment; however, the presented result was at odds with a former study on kohlrabi where the supplementation of digestate resulted in increased concentrations of this 
valuable compound. Cultivar differences might be responsible for these differences, but further studies are necessary to clarify the issue.

Author Contributions: Conceptualization, T.L. and J.E.; methodology, T.L. and T.V.; validation J.E., A.K. (Antonín Kintl), A.K. (Anna Keutgen), and N.K.; formal analysis, T.L., J.E., L.D. and J.Á.; investigation T.L., J.E., L.V., H.H. and K.G.; data curation, T.L. and T.V.; writing—original draft preparation T.L., A.K. (Anna Keutgen), N.K., M.M.-H. and J.E.; writing - review and editing, J.E., T.L., A.K. (Anna Keutgen) and N.K.; supervision, J.E.; project administration, J.E., T.L. and A.K. (Antonín Kintl); founding A.K. (Antonín Kintl). All authors have read and agreed to the published version of the manuscript.

Funding: This research was funded by the Internal Grant Agency of the Faculty of Agronomy, Mendel University in Brno No. TP 8/2014, and by the Internal Grant Agency of the Faculty of Regional Development and International Studies, Mendel University in Brno No. 10/2015. Above all, the research was funded by the Ministry of Agriculture of the Czech Republic, institutional support MZE-RO1720.

Acknowledgments: We express our thanks to the staff of the Botanical Garden and Arboretum of Mendel University in Brno for their help in these experiments.

Conflicts of Interest: The authors declare no conflict of interest.

\section{References}

1. Browne, J.D.; Murphy, J.D. Assessment of the resource associated with biomethane from food waste. Appl. Energy 2013, 104, 170-177. [CrossRef]

2. Siebielec, G.; Siebilec, S.; Lipski, D. Long-term impact of sewage sludge, digestate and mineral fertilizers on plant yield and soil biological activity. J. Clean. Prod. 2018, 187, 372-379. [CrossRef]

3. Möller, K.; Müller, T. Effects of anaerobic digestion on digestate nutrient availability and crop growth: A review. Eng. Life Sci. 2012, 12, 242-257. [CrossRef]

4. Lošák, T.; Hlušek, J.; Válka, T.; Elbl, J.; Vítěz, T.; Bělíková, H.; Bennewitz, E.A. The effect of fertilisation with digestate on kohlrabi yields and quality. Plant Soil Env. 2016, 62, 274-278. [CrossRef]

5. Stinner, W.; Möller, K.; Leithold, G. Effects of biogas digestion of clover/grass-leys, cover crops and crop residues on nitrogen cycle and crop yield in organic stockless farming systems. Eur. J. Agron 2008, 29, 125-134. [CrossRef]

6. Arthurson, V. Closing the global energy and nutrient cycles through application of biogas residue to agricultural land-potential benefits and drawbacks. Energies 2009, 2, 226-242. [CrossRef]

7. Gunnarsson, A.; Bengtsson, F.; Caspersen, S. Use efficiency of nitrogen from biodigested plant material by ryegrass. J. Plant Nutr. Soil Sci. 2010, 173, 113-119. [CrossRef]

8. Alburquerque, J.A.; Fuente, C.; Campoy, M.; Carrasco, L.; Nájera, I.; Baixauli, C.; Caravaca, F.; Roldán, A.; Cegarra, J.; Bernal, M.P. Agricultural use of digestate for horticultural crop production and improvement of soil properties. Eur. J. Agron. 2012, 43, 119-128. [CrossRef]

9. Ross, D.J.; Tate, K.R.; Speir, T.W.; Stewart, D.J.; Hewitt, A.E. Influence of biogas-digester effluent on crop growth and soil biochemical properties under rotational cropping. N. Z. J. Crop Hortic. Sci. 1989, 17, 77-87. [CrossRef]

10. Bath, B.; Elfstrand, S. Use of red clover-based green manure in leek cultivation. Biol. Agric. Hortic. 2008, 25, 269-286. [CrossRef]

11. Przygocka-Cyna, K.; Grzebisz, W. Biogas digestate-Benefits and risks for soil fertility and crop quality-An evaluation of grain maize response. Open Chem. 2018, 16, 258-271. [CrossRef]

12. Hlavinka, P.; Trnka, M.; Kersebaum, K.C.; Čermák, P.; Pohanková, E.; Orság, M.; Pokorný, E.; Fischer, M.; Brtnický, M.; Žalud, Z. Modelling of yields and soil nitrogen dynamics for crop rotations by HERMES under different climate and soil conditions in the Czech Republic. J. Agric. Sci. 2014, 152, 188-204. [CrossRef]

13. Handliř́ová, M.; Lukas, V.; Smutný, V. Yield and soil coverage of catch crops and their impact on the yield of spring barley. Plant Soil Environ. 2017, 63, 195-200.

14. Kren, J.; Klem, K.; Svobodová, I.; MíSa, P.; Lukas, V. Influence of sowing, nitrogen nutrition and weather conditions on stand structure and yield of spring barley. Cereal Res. Commun. 2015, 43, 326-335. [CrossRef]

15. Odlare, M.; Pell, M.; Svensson, K. Changes in soil chemical and microbiological properties during 4 years of application of various organic residues. Waste Manag. 2008, 28, 1246-1253. [CrossRef] [PubMed] 
16. Kolář, L.; Kužel, S.; Peterka, J.; Štindl, P.; Plát, V. Agrochemical value of organic matter of fermenter wastes in biogas production. Plant. Soil Environ. 2008, 54, 321-328. [CrossRef]

17. Möller, K.; Schulz, R.; Müller, T. Effects of setup of centralized biogas plants on crop acreage and balances of nutrients and soil humus. Nutr. Cycl. Agroecosyst. 2011, 89, 303-312. [CrossRef]

18. Lošák, T.; Zatloukalová, A.; Szostková, M.; Hlušek, J.; Fryč, J.; Vítěz, T. Comparison of the effectiveness of digestate and mineral fertilisers on yields and quality of kohlrabi (Brassica oleracea L.). Acta Univ. Agric. Silvic. Mendel. Brun. 2011, 59, 117-122.

19. Möller, K. Influence of different manuring systems with and without biogas digestion on soil organic matter and nitrogen inputs, flows and budget in organic cropping systems. Nutr. Cycl. Agroecosyst. 2009, 84, 179-202. [CrossRef]

20. Thomsen, I.K.; Olesen, J.E.; Møllerb, H.B.; Sørensena, P.; Christensena, B.T. Carbon dynamics and retention in soil after anaerobic digestion of dairy cattle feed and faeces. Soil Biol. Biochem. 2013, 58, 82-87. [CrossRef]

21. Šimon, T.; Kunzová, E.; Friedlová, M. The effect of digestate, cattle slurry and mineral fertilization on the winter wheat yield and soil quality parameters. Plant Soil Environ. 2015, 61, 522-527. [CrossRef]

22. Mozafar, A. Plant Vitamins, 1st ed.; CRC Press: Boca Raton, FL, USA, 2017; p. 422.

23. Zampelas, A.; Micha, R. Antioxidants in Health and Disease, 1st ed.; CRC Press: Boca Raton, FL, USA, 2016; p. 340 .

24. Koh, E.V.; Bissell, M.G.; Ito, R.K. Measurement of vitamin C by capillary electrophoresis in biological fluids and fruit beverages using a stereoisomer as an internal standard. J. Chromatogr. 1993, 633, 245-250. [CrossRef]

25. Steingrobe, G.; Schenk, M.K. Influence of nitrate concentration at the root surface on yield and nitrate uptake of kohlrabi (Brassica oleracea gongyloides L.) and spinach (Spinacia oleracea L.). Plant Soil 1991, 135, $205-211$. [CrossRef]

26. Feller, C.; Fink, M. Nitrogen uptake of kohlrabi, estimated by growth stages and an empirical growth model. J. Plant Nutr. Soil Sci. 1997, 160, 589-594.

27. Sharof, H.C.; Wier, U. Calculation of nitrogen immobilization and fixation. Gartenbau Hannover Germany. Bodenkunde 1994, 157, 11-16.

28. Mengel, K.; Kirkby, E.A. Principles of Plant Nutrition, 5th ed.; Kluwer Academic Publishers: London, UK, 2001.

29. Degryse, F.; Ajiboye, B.; Baird, R.; da Silva, R.C.; McLaughlin, M.J. Availability of fertiliser sulphate and elemental sulphur to canola in two consecutive crops. Plant Soil 2016, 398, 313-325. [CrossRef]

30. Petř́ḱková, K.; Hlušek, J.; Jánský, J.; Koudela, M.; Lošák, T.; Malý, I.; Pokluda, R.; Poláčková, J.; Rod, J.; Ryant, P.; et al. Zelenina-Pěstování, Ochrana, Výživa, Ekonomika, 1st ed.; Profi Press: Prague, Czech Republic, 2012.

31. Wang, Z.; Hassan, M.U.; Nadeem, F.; Wu, L.; Zhang, F.; Li, W. Magnesium Fertilization Improves Crop Yield in Most Production Systems: A Meta-Analysis. Front. Plant Sci. 2020, 10, 1727. [CrossRef] [PubMed]

32. Marschner, H. Mineral Nutrition of Higher Plants, 3rd ed.; Academic Press: London, UK, 2012.

33. Lošák, T.; Hlušek, J.; Kračmár, S.; Varga, L. The effect of nitrogen and sulphur fertilization on yield and quality of kohlrabi (Brassica oleracea L.). Rev. Bras. Cienc. Solo 2008, 32, 697-703.

34. Czech, A.; Malik, A. Content of nitrates V and III and heavy metals in selected Brassica vegetables depending on storage. J. Elem. 2012, 17, 201-213.

35. Schnug, E. Significance of sulphur for the quality of domesticated plants. In Sulphur Metabolism in Higher Plants: Molecular, Ecophysiological and Nutritional Aspects; Cram, W.J., De Kok, L.J., Brunold, C., Rennenberg, H., Eds.; Backhuys Publishers: Leiden, The Netherlands, 1997; pp. 109-130.

36. Paulsen, H.M. Schwefel und Nahrungsqualität. In Schwefel-Informaionstag der FAL Braunschweig; Institute of Organic Farming: Braunschweig, Deutschland, 2001.

37. Hlušek, J.; Richter, R.; Smatanová, M. Výživa a hnojení zelenin sírou. In Sbornik z Konference Racionální Použití Průmyslových Hnojiv; ČZU: Prague, Czech Republic, 2001; pp. 56-61.

38. Santamaria, P.; Elia, A.; Serio, F.; Gonnella, M.; Parente, A. Comparison between nitrate and ammonium nutrition fennel, celery and Swiss chard. J. Plant Nutr. 1999, 22, 1091-1106. [CrossRef]

39. Prosser, I.M.; Purves, J.V.; Saker, L.R.; Clarkson, D.T. Rapid disruption of nitrogen metabolism and nitrate transport in spinach plants deprived of sulphate. J. Exp. Bot. 2001, 52, 113-121. [CrossRef]

40. Kirchmann, H.; Witter, E. Composition of fresh, aerobic and anaerobic farm animal dungs. Bioresour. Technol. 1992, 40, 137-142. [CrossRef]

41. Lee, S.K.; Kader, A.A. Preharvest and postharvest factors influencing vitamin C content of horticultural crops. Postharvest Biol. Technol. 2000, 20, 207-220. [CrossRef] 
42. Han, D.F.; Wang, D.H.; Huang, P.Z.; Duan, J.X.; Ge, R.S.; Zhou, W.L. Effects of different morphology magnesium on yield and quality of 'Zaoshu 5' Chinese cabbage. Acta Hort. Sin. 2010, 37, 1655-1660.

43. Borowski, E.; Michalek, S. The effect of foliar nutrition of spinach (Spinacia oleracea L.) with magnesium salts and urea on gas exchange, leaf yield and quality. Acta Agrobot. 2010, 63, 77-85. [CrossRef]

44. Albrecht, J.A.; Schafer, H.W.; Zottola, E.A. Relationship of total sulfur to initial and retained ascorbic acid in selected cruciferous and noncruciferous vegetables. J. Food Sci. 1990, 55, 181-183. [CrossRef]

45. Mozafar, A. Nitrogen fertilizers and the amount of vitamins in plants: A review. J. Plant Nutr. 1993, 16, 2479-2506. [CrossRef]

46. Smatanová, M.; Richter, R.; Hlušek, J. Spinach and pepper response to nitrogen and sulphur fertilization. Plant Soil Environ. 2004, 50, 303-308. [CrossRef]

47. Nilson, T. The influence of soil type, nitrogen and irrigation on yield, quality and chemical composition of cauliflower. Swed. J. Agric. Res. 1980, 10, 65-75.

48. Maurya, A.N.; Chaurasia, S.N.S.; Reddy, Y.R.M. Effect of nitrogen and molybdenum levels on growth, yield and quality of cauliflower (Brassica oleracea var. Botrytis) cv. Snowball-16. Haryana J. Hort. Sci. 1992, 21, 232-235.

(C) 2020 by the authors. Licensee MDPI, Basel, Switzerland. This article is an open access article distributed under the terms and conditions of the Creative Commons Attribution (CC BY) license (http://creativecommons.org/licenses/by/4.0/). 